\title{
Terrorism in Popular Media: How Hollywood Represent Muslim Terrorist
}

\author{
Mundi Rahayu \\ mundirahayu@gmail.com \\ UIN Maulana Malik Ibrahim Malang \\ Mediyansyah \\ mediansyahtaharani@yahoo.co.id \\ UIN Maulana Malik Ibrahim Malang
}

\begin{abstract}
Movie has significant function not only as an entertainment but more importantly it also functions to document the historical events, to negotiate or even challenge the existing norms in the society. This paper discusses how Hollywood movies represent the discourse of Muslim terrorist. The movies share similar theme of Muslim terrorism; they are "The Siege" (1998) and "Syriana"(2005). The question presented here is how the movies represent the discourse of Muslim terrorism. This question critically addresses the issue of different faces of "Muslim terrorist" represented in the Hollywood films and the ideas or ideology underlied. The films are analysed through the lenses of critical discourse analysis (CDA). Fairclough's CDA discover the discourse through three levels of analysis, micro, meso and macro analysis. It aims to unravel how the Muslim terrorist is constructed by a particular group with a definite interest. Each of the movies has different causes, but they share similar use of "Muslim terrorism" as the vehicle of reaching the goals. The different context constructs the faces of terrorist in different ways. Muslim terrorist in Middle East context is represented in film "Syriana" with the background of oil business war. The Muslim terrorist in domestic context of the United States is represented in the film "The Siege" with the background of US foreign and domestic policy issues.
\end{abstract}

Keywords: CDA, Hollywood movies, Muslim terrorism, representation

\section{INTRODUCTION}

It is widely understood that popular culture product such as commercial films do not only function as merely entertainment. The film provides more than entertainment, it can reflect the sociocultural problems and the challenges that a society has to encounter in a particular time. According to Miles (1996). the popular product of film can be widely accepted by people, because it reflects audience' anxiety and longing, and capable of expressing —pressing concerns of a moment in history (Miles, 1996, p. x). In addition to this, Martin, J and Ostwalt, C (1995, p. vii) highlights that films have the potential to reinforce, to challenge, to overturn, or to crystallize religious perspectives, ideological assumptions, and fundamental values. The present article is aimed at unravelling the discourse of muslim terrorist as represented in the Hollywood films. The aim is related to the notion that by representing the muslim terrorist, the films are functioned as political tools to campaign a particular ideas.

The studies on American Hollywood cinema show that the cinema has long tradition of producing emotion, strengthening attachment and encouraging imitation in reflecting its 
relation to the East culture (Miles,1996: 3).this implies that the cinema is not only producing the visual work of entertainment, but it has built a strong cultural connection between western culture and eastern culture which refers to the vast areas of Asian and African countries. According to Ella Shohat (1990, p. 40-42) the relation of west and east is not a neutral nexus, instead, it is related to the colonial imagination of Hollywood and the evolution of West male gaze.

The terrorism is an issue popularly campaign by the US government especially after the 9/11 with the credo of "War on terrorism" that brought about the sending US Armies to many Muslim countries like Iraq, Libya, Afghanistan. Long before that, the historical root of terrorism is closely related to the socio-geo-political relation and contestation between western and eastern powers, that can be seen since the contestation and war of crusade between Christian and Muslim in Jerusalem in the first Century. Then, the Orientalism (1978) written by Edward Said highlighted the ways Western constructed the knowledge and power over the East. The orientalism brought about colonialism in the form of culture and knowledge that lasted long until recently. As there are many studies on the orientalism and colonial criticism, there is a few that highlight the specific issue of Muslim terrorist in the Hollywood cinema. The present article aimed at observing the colonial ideology underlying in the Hollywood films that presents the issue of Muslim terrorist. To make it specific, the questions presented in this study are, how is the discourse of Muslim terrorist represented in the two Hollywood films, and what is the ideology underlying the representation.

\section{LITERARY REVIEW}

\section{The Orient in the Eyes of Hollywood}

How Hollywood represent the eastern people and culture, is an important perspective to study. In a study on more than 900 Hollywood films, Shaheen (2001) finds out only 50 Arab figures, including Arab women, who are not represented as -erotic, wicked or humiliated and can not speak up her voice (Shaheen, 2001: 2), so almost majority of the Arab figures are misrepresented as -bomber, belly-dance and billionaire all of which connotate to bad guys. Shaheen's finding on Arab portrayal in Hollywood cinema is also supported by studies by Riegler (2009) and Ramji (2005), that Arab/Muslim are mostly stereotyped as villain, terrorist and bad guys in Hollywood cinema, highlighting the concept of Said's Orientalism (1979) that is still applied in this cultural product.

American Hollywood films have a dominant position in the film industry around the world. Crane's study on the domination of Hollywood in global world, concludes that the domination of the US film industry occurs in every country (Crane, 2014). Hollywood films and the films produced with Hollywood dominate the list of top 10 in global market and national market, although there is a policy of protection or national subsidy in each of countries. In can be concluded that there are two aspects that Hollywood cinema build from this domination. First, the financial profit as the result of films distribution around the world, and second, the cultural influence in disseminating American values (Crane 2014).

In political dimension, Hollywood cinema also has important role as a means of campaigning US agenda. Sally-Ann Totman (2009) in the book - How Hollywood Project Foreign Policy - analyses the relevance of US foreign policy and construction of the other ethnic or 
states in Hollywood films. Totman's analysis explores that film audience can understand the US' friends and enemy through what the authorities of Foreign Affairs office say and through what is said in Hollywood films. Film has been the device to project US foreign policy. When a particular nation is an enemy, it will be represented US a bad guy with all opposites American characteristics. On the contrary, allied countries will be represented US good guy, and friend (Totman, 2009: 1-2). This political roles makes Hollywood becomes part of American social political power in the global context.

\section{METHOD}

This research is a qualitative research, with cultural media approach. It applies Fairclough's Critical Discourse Analysis to explore the discourse of Muslim terrorist represented in Hollywood films, The Siege and Syrianna.

The data of this research are Hollywood films: The Siege (1998) and Syriana (2005). Film The Siege, was directed by Edward Zwick, tells about the Muslim terrorist operates in cells system, threatening to destroy and bomb many strategic places in New York. The threat is launched as the revenge of the capture of their religious leader by US Army. So, the terrorism in this context is related to the US foreign policy in Muslim country. The modus operandi of the terrorist in this film is believed by many as the pre-text of what happen in the 9/11 in 2001 .

The film Syriana (2005), narrates complexity politics and oil business of the multinational US corporation in Middle East, with the intervention of CIA, and involvement of the oil sheikh in Middle East. In the oil war business, the traditional Muslim group is represented as marginal and they are used as the weapon in the war in oil business.

\section{Data Collection}

Data collected in this research are in the form of text film, specifically in the form of phrase, sentence, and picture from the three films studied. Collecting the data is done through seeing and listening as well as making notes in detail on the films studied (The Siege and Syriana). The notes on the detail of naming choice, words, phrase, sentence, and picture in films. Verbal and non verbal data are taken of which is related to the theme of Muslim terrorist representation.

\section{Data Analysis}

The research applies Critical Discourse Analysis, which is a method that relates the language practice and social practice, bridged by discursive practice. Method of CDA, according to Wening Udasmoro (2014), admit the relationship between language produced with social practice done. The bridge between two is the practice of discourse. Social practice is done in many ways and it is dynamic because it is related to the previous social practices. Language has important roles in the social practice. Social and language practice occurs because of the consumption toward previous texts. Historical factor becomes important aspect that makes the dynamic of language and social practice.

The film text is analysed through three levels of analysis. The analysis is based on the three components: text, discourse practice, and social practice. The text analysis in Fairclough 
including the micro level analysis such as diction, words, vocabulary and syntax, and macro level is the social context of the text. Discourse analysis is related to the way a text is constructed, interpreted and distributed.

In the meso level, interaction of inter-discourse (discourse practice) covers the intertextuality, ideas or concept referred to by the actors. In this context, the discourse is related to each other discourse. Intertextuality and interdiscursivity is the reflection of consumption and reproduction of text. At third level, macro level, is the interpretation of social practice. This practice is analysed to interpret the practices by particular persons in practicing their power.

\section{RESULT}

\section{Representation of Muslim terrorist in Hollywood Films}

"The Siege" (1998) narrates a group of Muslim terrorist in the United States of America, operated in New York, who plotted to bomb at several places with the casualties of people in a big crowd. The bombing plot is planned as the revenge of the US CIA action of capturing their religious leader without an open judicial process. The plot of bombing is also meant to voice out their interest. They want to speak out laud their demand that the US authorities release their captured leader.

The specific term for the terrorism presented in this film is that terrorist operates in "cell system". The cell system means that they are not in a big group or an organization, instead it works in cells, in which each of the cell is one person. Sometimes, the one cell does not know each other, so that if one cell was caught by the police, the other cell will not be dragged. This cell system makes the authorities confused and difficult to track them down. Each of the cell can operates independently.

In the film The Siege the terrorists, a group of Arab looking man are represented as devoted Muslim with violent and demonic characteristics. The Arab men work in a network but applying cell system that allows them to work independently. They are Khalil, Samir, Ali Waziri and others. They are all Arabic men. Samir is Palestinian, and his older brother was dead of being suicide bomber at Tel. Aviv. The men are also represented as silly, temperamental, and uncivilized.

The film represents the suicide bomber as Muslim in many ways, the first is the cause of their mission. Their mission is to release their religious leader who was captured by US Army. The terrorist launches many threats to get their mission. Their Muslim leader is represented as an old men who always do prayer handling rosario in his hand, and he is mumbling, like reciting Quran. Whenever the general interrogated him, he is just mumbling. He could not speak English. The Muslim leader is always respected by the followers so that the young people has the sacred cause of saving the leader.

Second ways of representing the terrorist as Muslim is the Islamic ritual before they are doing their mission. As Muslim they are presented of doing their mission as a suicide bomber with the "ritual" that looks Islamic. Before the man go to explode himself, he took water for ablution and prepare the shroud. Taking ablution and wearing the shroud means that they are clean and purified physically. Like when Muslim is going to do Shalat (prayer), they have to do ablution, and wearing clean clothes. Wearing shroud is the ritual for funeral for Muslim. 
So it is obvious that the shroud is the symbol of their readiness to die in pure sacred mission. They are willing to die for the religious reason, in the ways that are religious too.

In "Syriana" (2005) -Muslim terrorist come up as the victim as well as the resistance force as the consequence of the complexity relation of American political economy interest in the Middle East. The "Syriana" narrates the competition of oil business between American oil company that operates in Middle East and the Chinese oil company. Beside that, there is contestation between the oil sheikhs, those who have the authorities on handling the business.

The terrorists are represented by a group of marginal young Muslim who are the workers in the oil company. The young men are migrant workers who come from Bangladesh, or other poor countries. The young men have no high education, instead, they got the informal education in the mosque. The religious teaching in the mosque is determined by the ustadz, religious teacher, who are easily influenced by other interested parties.

In the informal education at the mosques, the radical and resistance ideas are developed. Most of them in the mosques are the low class people, and they have no enough access economically, educationally, and politically. Seeing the development all over the world, they could do nothing because of their marginalized position. In this situation, the contested parties in the oil business deceive them and use them as the "suicide bomber" to kill their opponent.

This film represents in detail how the young boys are influenced and dictated to do their best in their life, that is to become suicide bomber. The bombing is constructed as a sacred Islamic mission, to save their life at the world after, and to safe their mother, and their family. They are taught that the world after is the best goal, much better than the life in the world. The mission is also prepared in a detail manner. They make the use of video to make speech to say goodbye, to do the mission in pride. The video is commonly seen together with their friends to give as example of the 'jihad' (doing the mission in the right path according to Allah) .

The detail of young people lives in poverty and 'traditional' teaching and interpretation of Islamic teaching complete the representation of Muslim as terrorist. Beside the cause to get better life in the world after, the suicide bomber also do that as the sacred cause of resistance to the modern world that marginalizes them, although they do not have clear ideas of who to resist. The modern world does not make them happier and wealthier at all. Their daily life seems exploited to work hard without enough facilities for life. Their condition of daily life is portrayed in detailed and in highly contrasted to the oil businessmen and the sheikhs who live in a very luxurious way, like dinner in a private yacht, living in a big mansion with abundance facilities.

\section{DISCUSSION}

The representation of Muslim terrorist in those two films have the similar notion, that is the Muslim terrorist are represented as the victims, marginalized parties in the geopolitical contestation of any powers.

In "The Siege" the Muslim terrorist are represented as the defeated group. They could not succeed to accomplish their mission. They are killed. In Syriana, the terrorists are marginalized young Muslim who are poor and exploited. At last they lost their jobs and want 
to get the better life by exploding themselves. They are indoctrinated with the teaching that the best reward they can get is the reward of afterlife.

In The Siege, we can find out the ideology of the US foreign policy that is unilateral, as world super power, but the action it has taken causes other bigger problem. What we can find out in the Siege is that there is always many interested parties in the operation of US foreign policies. In other words, there are many faces of the US policies in domestic and foreign affairs.

Ideologically, Syriana criticizes the practice of neoliberalism campaigned by corporation and the state (the United States of America). This conspiration of multinational corporation with CIA, leads to the reducing of international trust toward CIA and low international trust to USA. In this film, the death of the main character of CIA staff (Bob Baer) through the CIA's drone symbolizes the death of CIA conscience as institution representing the America in foreign operation. The bombing of the tanker with the name -Condolezza Ricell shows that symbolically USA has been the target of international resistance. This film criticizes the business practice of multinational corporation and its conspiration with CIA, but the construct -Muslim terrorist is strengthened with the Muslim radicalism developed in madrasah which is constructed as a site for reproducing the radical Islam.

Muslim group who are pro-West becomes the supporter of the western power to strengthen the hegemonic power, while marginalizing the resistant Muslim group. The three films construct the heroism for the American West Christian male, who represent the power who build and maintain the social order supported by Muslim group conforming the West. The resistant Muslim Arab, on the other hand, is constructed as the other. In The Siege the construct of hero is built to the figure of Anthony Hubbard, a black man the head of FBI -Task Force anti terrorll. With his position as the security officer responsible for the city, Hubbard is constructed as a hero who is very lawful, and in service to protect the people. In Syriana, the main character, Bob Baer is a white man of CIA member who is expert in the area of Middle East, able to speak in Arabic, Persian, beside English. Bob Baer's death in the CIA operation with the drone, symbolizes the question of CIA legitimation in advocating the Western or American values such as democracy and freedom.

\section{REFERENCE}

Bryant, Darrol M. 1982. "Cinema, Religion, and Popular Culture," in Religion in Film, eds., John R. May and Michael Bird. Knoxville: University of Tennessee Press.

Crane, Diana. 2014. Cultural globalization and the dominance of the American film industry: cultural policies, national film industries, and transnational film, International Journal of Cultural Policy, 20:4, 365-382, DOI:10.1080/10286632.2013.832233

Dick, Bernard F. 2005. Anatomy of Film 5th Ed. London: Palgrave Macmillan.

Durham, Gigi Meenakshi and Douglas M. Kellner.2006. Media and Cultural Studies; Keyworks. Revised Ed. Malden USA : Blackwell Publishing

El Fadl, Khaled Abou. 2005. The Great Theft: Wrestling Islam from the Extremists, New York: PerfectBound - HarperCollins Publisher Inc. 
Fairclough, Norman. 1989. Language and Power. UK: Longman Group UK Ltd.

Foucault, Michel. 1977. Discipline and Punish, London. Tavistock

Foucault, Michel. 1980. Power/Knowledge. Brighton: Harvester.

Foucault, Michel, 1981. "The Order of Discourse” dalam Robert Young (ed), Untying The Text: A Post-Structuralist Reader. Routledge.

Gardels, Nathan dan Medavoy, M. 2009. American Idol after Iraq : competing for hearts and minds in the global media age. UK: Wiley-Blackwell

Gerges, Fawaz A. 1999. America and Political Islam; Clash of Cultures or Clash of Interests? Cambridge University Press

Grossberg, Lawrence, Ellefn Wartella, D Charles Whitney, J. Macgregor Wise. 2006. Media Making: Mass Media in a Popular Culture. California: Sage Publication.

Habermas, Jurgen. The Public Sphere: An Encyclopedia in Durham, Meenakshi Gigi and Kellner, Douglas M. (ed). 2006.Media and Cultural Studies: Key Works, USA: Blackwell Publishing

Hall, Stuart. 1997. Representation Cultural Representations and Signifying Practice. USA: The Open University. Sage Publication. Ltd.

Halliday, Fred. 2003. Islam and the Myth of Confrontation 2nd Ed. London: LB Tauris

Hammer, Rhonda dan Douglas Kellner (ed). 2009. Media/Cultural Studies: Critical Approach. New York: Peter Lang Publication Inc.

Hinds, Harold, E., Marilyn F. Motz, Angela M.S. Nelson. 2006. Popular Culture Theory and Methodology; a Basic Introduction. USA: The University of Wisconsin Press.

Kellner, Douglas.2004. 9/11, Spectacles of terror, and Media Manipulation, Critical Discourse Studies, 1:1, 41-64, DOI: 10.1080/17405900410001674515

Kellner, Douglas. 2003. From 9/11 to Terror War: The Danger of Bush legacy. Maryland: Rowman \& Littlefield Publishers, Inc.

Khatib, Lina. 2006. Filming the Modern Middle East: Politics in the Cinema of Hollywood and the Arab World. London: IB Tauris.

Lewis, Simon. 2014. What Is Spectacle?, Journal of Popular Film and Television, 42:4, 214221, DOI: $10.1080 / 01956051.2014 .923370$

Ramji, Rubina. 2005. "From Navy Seals to The Siege: Getting to Know the Muslim Terrorist, Hollywood Style". The Journal of Religion and Film Vol. 9 No. 2. October 2005. (http://www.unomaha.edu/ jrf/Vol9No2/RamjiIslam.htm)

Riegler, Thomas. 2009. Through the Lenses of Hollywood: depictions of Terrorism in American Movies.

Said, Edward W. 1978. Orientalism. New York: Vintage Books Edition. 
Shaheen, Jack. 2000. Hollywood's Muslim Arabs. The Muslim World Vol. 90. http://macdolad.hartsem.edu/articles/shaheenart1.pdf

Shaheen, Jack. 2001. Reel Bad Arabs: How Hollywood Vilifies a People. New York: Olive Branch Press.

Totman, Sally-Ann. 2009. How Hollywood Projects Foreign Policy. New York:

Palgrave Macmillan.

Udasmoro, Wening, dkk. 2014. Konstruksi Identitas Remaja dalam Karya Sastra.

Yogyakarta: Program Studi Sastra Perancis - FIB UGM. 